\title{
Isolation, characterization, and molecular identification of soil bacteria showing antibacterial activity against human pathogenic bacteria
}

\author{
R. Prashanthi", Shreevatsa G.K., Krupalini S. and Manoj L.
}

\begin{abstract}
Background: The present study dealt with the screening of soil bacteria with antibacterial activity from different locations in Bangalore, India. Antibiotics play the role of self-defense mechanism for the bacteria and are produced as secondary metabolites to protect themselves from other competitive microorganisms. The need for new antibiotics arose as the pathogenic bacteria acquire resistance to various antibiotics meant for treating human diseases. Given the importance of antibiotics of bacterial origin, standard techniques have been used to isolate and characterize the soil bacteria which showed antibacterial activity.

Results: The isolated bacteria were tested against human pathogenic bacteria like Staphylococcus aureus, Escherichia coli, Pseudomonas aeruginosa, and Klebsiella pneumoniae by primary and secondary screening methods. The isolates PR1, PR2, and PR3 were confirmed to have antibacterial activity against S. aureus, E. coli, P. aeruginosa, and $K$. pneumoniae by both methods. Studies on the effect of filter sterilization, autoclaving, and proteinase K treatment on culture filtrates showed filter sterilization as the best method. The effect of different carbon and nitrogen sources on the antibacterial activity showed that preference by each isolate differed for carbon and nitrogen requirements. The isolates PR1, PR2, and PR3 were identified as Bacillus aryabhattai strain PR-D07, Arthrobacter humicola strain PR-F07, and Neomicrococcus lactis strain PR-F11 through 16S rRNA sequencing.

Conclusion: Findings from this research work are encouraging and could proceed further to applied aspects. Only 3 bacterial isolates out of 263 isolates from soil samples displayed antibacterial activity against human pathogens $S$. aureus, E. coli, P. aeruginosa, and K. pneumoniae. They were identified as B. aryabhattai, A. humicola, and N. lactis by $16 \mathrm{~S}$ rRNA studies and all of them are Gram-positive. Each isolate preferred different carbon and nitrogen sources for their enhanced antibacterial activity. Efficacy of the culture filtrates of these isolates was tested by filter sterilization, autoclaving, and proteinase $\mathrm{K}$ treatment. Filter-sterilized culture filtrates showed higher antibacterial activity than other treatments. A comparison of the antibacterial activity of culture filtrates and antibiotic streptomycin produced an inhibition zone of $18.5 \mathrm{~mm}$ and $15.5 \mathrm{~mm}$ respectively. This is the first report on the antibacterial activity of all the 3 bacterial strains (B. aryabhattai strain PR-D07, A. humicola strain PR-F07, and N. lactis strain PR-F11), against all the human pathogens, mentioned earlier. It is also found that the antibiotic factor is proteinaceous as proteinase $\mathrm{K}$ considerably reduced the antibacterial activity of the culture filtrates. With the above significant results, these 3 bacteria are considered to be promising candidates for the isolation of new antibacterial agents.
\end{abstract}

Keywords: Soil bacterial communities, 165 rRNA sequencing, Antagonistic activity

\footnotetext{
* Correspondence: prashanthibt10@gmail.com

Department of Biotechnology and Genetics, M. S. Ramaiah College of Arts,

Science and Commerce, Karnataka 560054 Bengaluru, India
}

\section{Springer Open}

(- The Author(s). 2021 Open Access This article is licensed under a Creative Commons Attribution 4.0 International License, which permits use, sharing, adaptation, distribution and reproduction in any medium or format, as long as you give appropriate credit to the original author(s) and the source, provide a link to the Creative Commons licence, and indicate if changes were made. The images or other third party material in this article are included in the article's Creative Commons licence, unless indicated otherwise in a credit line to the material. If material is not included in the article's Creative Commons licence and your intended use is not permitted by statutory regulation or exceeds the permitted use, you will need to obtain permission directly from the copyright holder. To view a copy of this licence, visit http://creativecommons.org/licenses/by/4.0/. 


\section{Background}

The existence of a large microbial community in the soil is supported by an enormous group of organic matters in the earth. Most of these microorganisms are bioactive and survive at the top few inches of the agricultural soils [1]. The microorganisms can live in several habitats along with humans and also in the utmost condition such as inside the rocks of the oceanic crust [2], cold temperature [3], hot springs [4], and miles deep in the ocean [5]. Abiotic and biotic factors are involved in regulating the activity and diversification of soil microorganisms. The presence of microbes in soil is based on the existence of ambient conditions provided by the types of vegetation, the texture and chemical nature of the soil, nutrients availability, $\mathrm{pH}$, moisture content, climate, and temperature. The physiology of the soil is also determined by all these conditions as it varies across the same place between different seasons. Further, the dumping of the organic wastes from agricultural fields ensures the availability of the high nutrient content in soil for the growth of the microorganisms [6]. Some bacterial communities in the soil such as Thiobacillus, Rhizobium, Nitrosomonas, Clostridium, Nitrobacter, Caulobacter, Pseudomonas, and Frankia carry out an essential task in nutrient cycling [7].

During the past decades, an enormous number of bacteria that produce a diverse kind of primary and secondary metabolites, enzymes, antibiotics, and novel compounds, etc., were isolated $[8,9]$, identified, and exploited by several research groups in human health care, agriculture, and animal husbandry, etc. As these compounds have a unique structure, microorganisms continue to be the essential source of secondary metabolites. The uniqueness of the secondary metabolite is that they act as an antimicrobial agent towards pathogenic bacteria. Antibiotics are not necessary for the growth of bacteria but they help the survival of bacteria [10]. The bacterial community remains the major source of antibiotic production which is widely used in human health care. Each year, nearly 500 antibiotics are discovered, in which most of the antibiotics are obtained from the soil bacteria [11, 12]. Antibiotics are low-molecular-mass $(<1500 \mathrm{kDa})$ products of secondary metabolism, usually produced during the late growth phase (idiophase) of a relatively small group of microorganisms [10]. Antibiotics play the role of a self-defense mechanism for the bacteria and are produced as secondary metabolites to protect themselves from other competitive microorganisms [13]. Most of the antibiotics which are currently in use are produced from a small group of microorganisms belonging to the genera Penicillium, Streptomyces, Cephalosporium, Micomonospora, and Bacillus [14]. Members of the species Bacillus generally produce polypeptide-type bacteriocins, and these antibiotics are generally effective against several Grampositive bacteria $[15,16]$.

India was the largest user of antibiotics with $12.9 \times$ $10^{9}$ units (10.7 units per person) as per the data available for 2010 [17]. The demand for bacterial antibiotics continues to increase globally owing to the pathogenic bacteria acquiring resistance to existing antibiotics and many antibiotics proved that they are no longer potent against the infections $[18,19]$. Multidrug resistance in bacteria raised serious concerns among pharmaceutical and healthcare researchers. It puts greater pressure among researchers to find alternative antibacterial substances that can be used for use in clinics, food preservation, and dairy products $[20,21]$. The indiscriminate use of antibiotics and their improper disposal lead to drug resistance in pathogenic bacteria and the antibiotics become less effective for their use. At present, modern medicine is facing a tremendous challenge to combat the antibiotic resistance acquired by several pathogenic species. Antibiotics are aimed to inhibit the growth or kill the microbes that cause infectious diseases and drug resistance is considered a threat to health security [22]. To survive the adverse environment, bacteria evolve mechanisms to modify or acquire new genes through natural ways and eliminate the effectiveness of drugs [23].

An incomplete dose of any prescribed antibiotic also facilitates the pathogenic bacteria to develop resistance. This necessitates a situation to find new antibiotics to meet the drug resistance challenges. Considering these in mind, this study was focused on isolation and characterization of antibiotic-producing bacteria from the soil in 7 different sites like the garden, the playground, near the canteen, and near the sewage sump covered with vegetation. In this study, we have found that some soil bacteria displayed antibacterial activity and they are characterized and identified using molecular methods.

\section{Method \\ Collection of soil sample}

The soil collection site is located in and around with a lot of native vegetation at an altitude of $949 \mathrm{~m}$ with a latitude and longitude of $12.87^{\circ} \mathrm{N}, 77.59^{\circ} \mathrm{E}$. The types of soil in the location consist of red laterite and fine loamy to clayey. The debris from the soil surface was removed before the collection of soil samples. The soil was dug into 5-10-cm depth. About $20 \mathrm{~g}$ of the soil samples were collected and stored in an icebox before transporting to the laboratory.

\section{Pathogenic bacteria and culture conditions}

The standard serial dilution technique was used for the isolation of bacteria from soil samples collected from 7 different sites like the garden, the playground, near the 
canteen, near the sewage sump, near the biotechnology department, near RIT, and RUAPS. One gram of soil sample was mixed with $10 \mathrm{ml}$ of sterile water and serially diluted $\left(10^{-1}\right.$ to $\left.10^{-4}\right)$. From the serially diluted soil sample, $100 \mu \mathrm{l}$ was mixed with warm nutrient agar medium and poured into Petri plates. Natamycin (Sigma-Aldrich, USA) at $20 \mu \mathrm{g} / \mathrm{ml}$ was amended with a molten nutrient agar medium at $50 \mathrm{C}$ to prevent fungal growth $[24,25]$. After $48 \mathrm{~h}$, the plates had a lawn of mixed bacterial colonies. The individual colonies were picked using sterile toothpicks and streaked onto fresh nutrient agar plates to get pure cultures. The pure culture was stored and used for testing antibacterial activity against human pathogenic bacteria Staphylococcus aureus (MTCC 96), Escherichia coli (MTCC 739), Pseudomonas aeruginosa (MTCC 741), and Klebsiella pneumoniae (MTCC 3040). The concentration of all pathogenic bacteria was adjusted to obtain the OD $=0.8$ using a UV/Vis spectrophotometer at $600 \mathrm{~nm}$.

\section{Primary screening}

A total of 263 bacterial colonies were isolated from soil samples collected from 7 different sites. Initial screening of the 263 soil bacteria for antagonistic activity was done in an in vitro condition against pathogenic bacteria like Staphylococcus aureus (MTCC 96), Escherichia coli (MTCC 739), Pseudomonas aeruginosa (MTCC 741), and Klebsiella pneumoniae (MTCC 3040) through perpendicular streaking [26] and seed overlay method [27]. The bacteria from the soil sample were individually streaked as a single straight line through the central point of the nutrient agar plates. All the pathogenic bacteria were perpendicularly streaked to the soil bacteria [26]. The plates were incubated for $24 \mathrm{~h}$ to find any inhibition zone between soil bacteria and the pathogenic bacteria. The bacterial strains showing an inhibition zone against test pathogens were chosen for secondary screening.

\section{Seed overlay method}

The isolated soil bacteria were inoculated using a sterile toothpick in a nutrient agar plate and incubated for $48 \mathrm{~h}$ followed by the addition of $2 \mathrm{ml}$ of chloroform to arrest the growth of the inoculated bacteria. The plates were incubated for $1 \mathrm{~h}$ to ensure only the secondary metabolites from the inoculums remain active on the nutrient agar plate. The plates were kept open for $20 \mathrm{~min}$ for the evaporation of the chloroform. Then, $100 \mu$ lof each pathogenic bacterium $(\mathrm{OD}=0.8)$ was mixed with $2 \mathrm{ml}$ of nutrient broth and mixed thoroughly. The medium was transferred to the above agar plate and incubated for $24 \mathrm{~h}$. The activity of the secondary metabolites against pathogenic bacteria was indicated by the diameter of the inhibition zone [27]. The bacteria which produced the inhibition zone were chosen for secondary screening.

\section{Secondary screening to confirm antibacterial activities}

All the active bacteria selected from the primary screening method were grown separately in Nutrient broth at $30{ }^{\circ} \mathrm{C}$ under shaking conditions. After $24 \mathrm{~h}$, the nutrient broth with cells was adjusted to get an OD of 0.8 at 600 $\mathrm{nm}$ using a UV/Visible spectrophotometer (SYSTRONICS, India, Model: AU-2702). It was centrifuged at $5000 \times \mathrm{g}$ for $10 \mathrm{~min}$ in a centrifuge (Remi, Model: CPR24Plus) and cell free-culture filtrate was collected and stored at $4{ }^{\circ} \mathrm{C}$.

The minimum inhibitory concentrations (MICs) of the culture filtrate were determined by using the Agar Well Diffusion method. Nutrient agar plates were inoculated with $100 \mu \mathrm{l}$ of the pathogenic organism by the spread plate method. Using a 6-mm-diameter cork borer, 2 wells were made in agar plates at equal distances and the wells were filled with $50 \mu \mathrm{l}$, and $100 \mu \mathrm{l}$, of cell-free culture filtrates of PR1, PR2, and PR3 separately. Then, the filter paper disc about $6 \mathrm{~mm}$ in diameter impregnated with streptomycin $(20 \mu \mathrm{l}$,) was placed on the agar surface. Streptomycin discs were used as a positive control. The agar plates were incubated for 2 days at $30{ }^{\circ} \mathrm{C}$ for bacterial growth. Antibacterial activity of culture filtrate was determined by measuring the zone of inhibition (Kirby-Bauer Test) around the well [28].

\section{Effect of filter sterilization, autoclaving, and proteinase $\mathrm{K}$ treatment on culture filtrate}

To test the efficacy of culture filtrates of PR1, PR2, and PR3 as a sustainable antibacterial agent, they were subjected to (a) filtering through a $0.45-\mu \mathrm{m}$ Millipore filter (b), autoclaving at $121{ }^{\circ} \mathrm{C}$ for $20 \mathrm{~min}$, and (c) treating with proteinase $\mathrm{K}(0.02 \mathrm{mg} / \mathrm{ml})$ at $50{ }^{\circ} \mathrm{C}$ for $1 \mathrm{~h}$. Antibacterial activity was tested using the following: (1) crude cell-free culture filtrate, (2), filter-sterilized culture filtrate, (3), filter-sterilized + heat-sterilized, and (4), filter-sterilized + proteinase K. Inhibition zone for each treatment was measured and presented.

\section{Effect of carbon and nitrogen sources on antibacterial activity}

The effect of different carbon and nitrogen sources on the antibacterial activity of the culture filtrates of PR1, PR2, and PR3 was studied. Fifty milliliters of the synthetic medium amended with various carbon (1\%) and nitrogen (0.3\%) sources was distributed into each $250-\mathrm{ml}$ Erlenmeyer flask and sterilized. The composition of the synthetic medium was sucrose $10 \mathrm{~g}, \mathrm{~K}_{2} \mathrm{HPO}_{4} 1.2 \mathrm{~g}$, $\mathrm{KH}_{2} \mathrm{PO}_{4} 0.8 \mathrm{~g}, \mathrm{MgSO} 47 \mathrm{H}_{2} \mathrm{O} 0.2 \mathrm{~g}, \mathrm{NH}_{4} \mathrm{NO}_{3} 0.3 \mathrm{~g}$, water $1000 \mathrm{ml}$, and $\mathrm{pH}$ 6.8-7.00. Arabinose, fructose, galactose, glucose, lactose, maltose, mannitol, and sucrose were used 
as carbon sources. Casein, $\mathrm{NH}_{4} \mathrm{Cl}, \mathrm{NH}_{4} \mathrm{NO}_{3}, \mathrm{NaNO}_{3}$, $\mathrm{NH}_{4} \mathrm{H}_{2} \mathrm{PO}_{4}, \mathrm{KNO}_{3},(\mathrm{NH} 4)_{2} \mathrm{SO} 4$, and urea were used as nitrogen sources. After inoculation with PR1, PR2, and PR3, the flasks were incubated at $30{ }^{\circ} \mathrm{C}$ for $48 \mathrm{~h}$. under shaking conditions. At the end of $48 \mathrm{~h}$, the liquid cultures of PR1, PR2, and PR3 were centrifuged at $5000 \times \mathrm{g}$ in a centrifuge. Cell-free culture filtrates were collected and stored at $4{ }^{\circ} \mathrm{C}$.

\section{Morphological and biochemical analysis of bacteria}

Morphological and biochemical characterizations of the bacteria that showed antibacterial activity was carried out using standard techniques described in Bergey's Manual of Determinative Bacteriology. Bacteria grown for $24 \mathrm{~h}$ in the nutrient broth were used for Gram staining and biochemical characterization.

\section{Molecular identification of bacteria}

Overnight-grown cultures of PR1, PR2, and PR3 were used for DNA isolation. About $2.0 \mathrm{ml}$ of bacterial suspension was transferred to a microcentrifuge tube and centrifuged for $2 \mathrm{~min}$ at $10,000 \times \mathrm{g}$ to collect the pellet. The above process was repeated twice with $2.0 \mathrm{ml}$ of bacterial suspension to obtain a sufficient number of cells. The cells were washed with $0.9 \%$ saline and $0.2 \mathrm{ml}$ protease was added to digest and remove the protein and cellular materials to release the genomic DNA. The centrifuged tubes were inverted 5-6 times and kept in a boiling water bath for $1 \mathrm{~h}$ at $55^{\circ} \mathrm{C}$. After $1 \mathrm{~h}, 0.1 \mathrm{ml}$ of the DNA Salt solution was added and centrifuged for 5 $\mathrm{min}$ at $5,000 \times \mathrm{g}$. Finally, $0.8 \mathrm{ml}$ of the precipitated solution was added slowly and the centrifuge tube inverted several times to mix the components. $70 \%$ ethanol was used to wash the cells. The collected DNA were dried and suspended in TE buffer and stored at $4{ }^{\circ} \mathrm{C}$. The quality and integrity of the isolated genomic DNA were quantified at wavelength 260 and $280 \mathrm{~nm}$ using a spectrophotometer. The purity of the extracted DNA was checked on $08 \%$ agarose gel.

For the amplification of the 16S rRNA gene fragments the universal primers were used (forward primer 5'AGAGTTTGATCCTGGCTCAG-3' and reverse primer 5'-GGTTACCTTGTTACGACT-3'). PCR parameters were initial denaturation at $95{ }^{\circ} \mathrm{C}$ for $5 \mathrm{~min}$; followed by 30 cycles of denaturation at $94{ }^{\circ} \mathrm{C}$ for $1 \mathrm{~min}$; annealing at $54{ }^{\circ} \mathrm{C}$ for $2 \mathrm{~min}$; extension at $72{ }^{\circ} \mathrm{C}$ for $2 \mathrm{~min}$; final extension at $72{ }^{\circ} \mathrm{C}$ for $5 \mathrm{~min}$. The amplified PCR products were electrophoresed on an agarose gel [29].

Amplified 16S rRNA gene fragments were purified and sequenced using a DNA sequencing service. The obtained 16S rRNA gene sequences were uploaded to the Basic Local Alignment Search Tool (BLAST) to identify nucleotide sequence matching with the reference sequences.

\section{Results}

Soil sample

The soil samples from 7 sites were serially diluted and spread on Nutrient agar plates and incubated at $30 \mathrm{C}$ for 3 days. A total of 263 bacterial colonies were isolated from all the sites mentioned earlier. Individual colonies were picked and inoculated into Petri plates containing nutrient agar medium and incubated at $30{ }^{\circ} \mathrm{C}$. A maximum number of colonies were noticed in soil samples collected from the garden, near the sewage sump, and near the canteen compared to other soil samples (Table 1).

\section{Primary screening for antibacterial activity}

All the 263 bacterial isolates were tested for their antibacterial activity against pathogenic bacteria $S$. aureus, E. coli, $P$. aeruginosa, and $K$. pneumoniae using primary screening. The results of the primary screening showed that only 2 isolates (PR1 and PR2) from garden soil and one isolate (PR3) from the soil collected near the sewage sump had antibacterial activity against all the tested bacteria (Table 2). The isolates PR1, PR2, and PR3 were selected for secondary screening.

\section{Secondary screening for antibacterial activity}

The 3 isolates PR1, PR2 \& PR3 which were confirmed to have antibacterial activity through primary screening were subjected to secondary screening for further confirmation of their activity against human pathogens S. aureus, E. coli, $P$. aeruginosa, and $K$. pneumoniae. All culture filtrates at $100 \mu \mathrm{l}$ showed a maximum inhibition zone except $E$. coli indicating that Gram (+) bacteria are susceptible to antibiotics than Gram (-) bacteria. The filter-sterilized culture filtrate of PR1 showed a maximum zone of inhibition with $15.5 \mathrm{~mm}, 10.0 \mathrm{~mm}, 15.0 \mathrm{~mm}$, and $14.0 \mathrm{~mm}$ compared to PR2 and PR3 against the tested pathogens (Table 3). Although all the isolates showed antibacterial activity against all pathogenic bacteria, autoclaved and proteinase K-treated culture filtrates lost their activity by 30 to $40 \%$ (Table 4 ) indicating that filter sterilization of crude culture filtrate is the best option for testing antibacterial activity. The inhibition zone for standard antibiotic streptomycin was 17.5 to $18.5 \mathrm{~mm}$ depending on the pathogens.

\section{Effect of carbon and nitrogen sources on antibacterial activity}

Studies on the effect of different carbon and nitrogen source on the antibiotic activity revealed that Glycerol and Urea were the preferred carbon and nitrogen source for the isolate PR1. Isolate PR2 preferred Glucose and Casein while PR3 preferred sucrose and casein. Nutrient preference varied among all the isolates tested. Among the 4 test organisms, the inhibition zone for the Gramnegative bacterium $E$. coli was smaller than all other bacteria (Table 5). Commercial antibiotic streptomycin showed 
Table 1 Bacteria from soil samples

\begin{tabular}{|c|c|c|c|c|}
\hline Soil sample (location) & Dilution & $\mathrm{CFU} / \mathrm{ml}$ & No. of colonies & Antibacterial activity \\
\hline Garden & $10^{-3}$ & $9.8 \times 10^{6}$ & 69 & PR1, PR2 \\
\hline Playground & $10^{-2}$ & $4.5 \times 10^{6}$ & 15 & Nil \\
\hline Near canteen & $10^{-3}$ & $8.7 \times 10^{5}$ & 48 & Nil \\
\hline Near sewage sump & $10^{-3}$ & $9.2 \times 10^{6}$ & 54 & PR3 \\
\hline Near biotech dept. & $10^{-3}$ & $4.5 \times 10^{6}$ & 45 & Nil \\
\hline Near RIT & $10^{-3}$ & $3.5 \times 10^{5}$ & 12 & $\mathrm{Nil}$ \\
\hline Near RUAPS & $10^{-3}$ & $5.5 \times 10^{6}$ & 20 & Nil \\
\hline Total & & & 263 & 3 \\
\hline
\end{tabular}

a larger inhibition zone than all the culture filtrates. A synthetic medium with sucrose and ammonium nitrate as carbon and nitrogen source was used as a control.

\section{Morphological and biochemical characterization of antagonistic bacteria}

The morphological and biochemical characterization of bacterial isolates PR1, PR2, and PR3 which showed antibacterial activity were done, and results are tabulated (Table 6).

\section{Molecular identification of bacteria}

The isolation of genomic DNA was carried out to obtain pure DNA from the isolates PR1, PR2, and PR3. The 16sRNA was amplified from the isolated DNA sample using PCR. $1.2 \%$ of agarose gel was used to verify the amplified products which showed a fragment of $1.5 \mathrm{~kb}$.

The amplified 16s r RNA of PR1, PR2, and PR3 were subjected to purification and sequencing. The sequences of PR1, PR2, and PR3 were submitted to NCBI. The accession numbers of the sequence PR1, PR2, and PR3 are MT453908-Bacillus aryabhattai strain PR-D07, MT453911-Arthrobacter humicola strain PR-F07, and MT453912-Neomicrococcus lactis strain PR-F11.

The sequence of MT453908-Bacillus aryabhattai strain PR-D07

TATCCCCGGGAGCCCGACCCGGCGCCGCAAGT CGGAACCAGGTACCCGTATAGTTTGATCCTGGCT CAGG

ATGAACGCTGGCGGCGTGCCTAATACATGCAA GTCGAGCGAACTGATTAGAAGCTTGCTTCTATGA CGTT

Table 2 Antibacterial activity against pathogenic bacteria by primary screening

\begin{tabular}{lllll}
\hline Isolates & S. aureus & E. coli & P. aeruginosa & K. pneumoniae \\
\hline $\mathrm{PR} 1$ & + & + & + & + \\
$\mathrm{PR} 2$ & + & + & + & + \\
$\mathrm{PR} 3$ & + & + & + & + \\
\hline
\end{tabular}

AGCGGCGGACGGGTGAGTAACACGTGGGCAAC CTGCCTGTAAGACTGGGATAACTTCGGGAAAC CGAAGC

TAATACCGGATAGGATCTTCTCCTTCATGG GAGATGATTGAAAGATGGTTTCGGCTATCACTTA CAGATG

GGCCCGCGGTGCATTAGCTAGTTGGTGAGGTA

ACGGCTCACCAAGGCAACGATGCATAGCCGAC

CTGAGA

GGGTGATCGGCCACACTGGGACTGAGACACGG

CCCAGACTCCTACGGGAGGCAGCAGTAGGGAA

TCTTCC

GCAATGGACGAAAGTCTGACGGAGCAACGCCG

CGTGAGTGATGAAGGCTTTCGGGTCGTAAAAC

TCTGTT

GTTAGGGAAGAACAAGTACAAGAGTAACTGCT

TGTACCTTGACGGTACCTAACCAGAAAGCCACGG

CTAA

CTACGTGCCAGCAGCCGCGGTAATACGTAG GTGGCAAGCGTTATCCGGAATTATTGGGCG

TAAAGCGCGC

GCAGGCGGTTTCTTAAGTCTGATGTGAAAGCC

CACGGCTCAACCGTGGAGGGTCATTGGAAA

CTGGGGAA

CTTGAGTGCAGAAGAGAAAAGCGGAATTCCAC

GTGTAGCGGTGAAATGCGTAGAGATGTGGA

GGAACACC

AGTGGCGAAGGCGGCTTTTTGGTCTGTAACTG

ACGCTGAGGCGCGAAAGCGTGGGGAGCAAA

CAGGATTA

GATACCCTGGTAGTCCACGCCGTAAACGATGAGTGC

TAAGTGTTAGAGGGTTTCCGCCCTTTAGTGCTGC

AGCTAACGC

The sequence of MT453911-Arthrobacter humicola strain PR-F07

TCAAACTCCCTTAGATTTGATCCTGGCTCAGG ACGAACGCTGGCGGCGTGCTTAACACATGCAA

GTCGAA

CGATGATCCGGTGCTTGCACCGGGGATTAGTG GCGAACGGGTGAGTAACACGTGAGTAACCTGC CCTTGA 
Table 3 Antibacterial activity of culture filtrate of PR1, PR2, and PR3 against pathogenic bacteria

\begin{tabular}{|c|c|c|c|c|c|}
\hline Isolates & $\begin{array}{c}\text { Pathogenic bacteria } \\
\qquad(\mathrm{OD}=0.8)\end{array}$ & $\begin{array}{c}\text { Culture } \\
\text { filtrate } \\
50 \mu 1 \\
\end{array}$ & $\begin{array}{l}\text { Culture } \\
\text { filtrate } \\
100 \mu 1 \\
\end{array}$ & $\begin{array}{c}\text { Filter sterilized } \\
\text { Culture filtrate } \\
50 \mu 1 \\
\end{array}$ & $\begin{array}{c}\text { Filter sterilized } \\
\text { Culture filtrate } \\
100 \mu 1\end{array}$ \\
\hline \multirow{4}{*}{ PR1 } & S. aureus & $11.5 \pm 0.1^{*}$ & $12.5 \pm 0.1^{*}$ & $13.5 \pm 0.1^{*}$ & $15.5 \pm 0.1^{*}$ \\
\hline & E. coli & $9.0 \pm 0.2^{*}$ & $10.0 \pm 0.2 *$ & $9.5 \pm 0.1^{*}$ & $10.0 \pm 0.1^{*}$ \\
\hline & P. aeruginosa & $11.5 \pm 0.2^{*}$ & $12.0 \pm 0.5^{*}$ & $13.5 \pm 0.1 *$ & $15.0 \pm 0.1 *$ \\
\hline & K. pneumoniae & $10.5 \pm 0.1^{*}$ & $11.0 \pm 0.1^{*}$ & $13.5 \pm 0.1^{*}$ & $14.0 \pm 0.1^{*}$ \\
\hline \multirow{4}{*}{ PR2 } & S. aureus & $12.0 \pm 0.2^{*}$ & $12.0 \pm 0.2^{*}$ & $13.0 \pm 0.1^{*}$ & $14.0 \pm 0.1^{*}$ \\
\hline & E. coli & $8.0 \pm 0.1^{*}$ & $9.5 \pm 0.2^{*}$ & $9.5 \pm 0.1^{*}$ & $10.5 \pm 0.1 *$ \\
\hline & P. aeruginosa & $10.0 \pm 0.1^{*}$ & $11.0 \pm 0.1^{*}$ & $11.0 \pm 0.1^{*}$ & $12.0 \pm 0.1^{*}$ \\
\hline & K. pneumoniae & $10.5 \pm 0.1^{*}$ & $11.0 \pm 0.1^{*}$ & $10.5 \pm 0.1 *$ & $11.0 \pm 0.1 *$ \\
\hline \multirow{4}{*}{ PR3 } & S. aureus & $12.5 \pm 0.2^{*}$ & $13.5 \pm 0.3^{*}$ & $12.5 \pm 0.1^{*}$ & $14.5 \pm 0.1^{*}$ \\
\hline & E. coli & $8.0 \pm 0.1 *$ & $9.0 \pm 0.2^{*}$ & $7.5 \pm 0.1^{*}$ & $8.0 \pm 0.1^{*}$ \\
\hline & P. aeruginosa & $11.5 \pm 0.1^{*}$ & $13.5 \pm 0.2^{*}$ & $12.5 \pm 0.1^{*}$ & $13.5 \pm 0.1^{*}$ \\
\hline & K. pneumoniae & $10.5 \pm 0.1^{*}$ & $11.0 \pm 0.2 *$ & $11.5 \pm 0.1^{*}$ & $12.0 \pm 0.1^{*}$ \\
\hline
\end{tabular}

Results are expressed as antagonistic activity $(\mathrm{mm})$ of the isolate bacteria against pathogenic compared to control (mean $\pm \mathrm{SD}, n=3$ ). Values significantly different from control if ${ }^{*} \rho<0.05$ as analyzed by Student's $t$-test. Control value for all the pathogenic bacteria $6 \mathrm{~mm}$

PR1-Bacillus aryabhattai strain PR-D07, PR2-Arthrobacter humicola strain PR-F07, PR-Neomicrococcus lactis strain PR-F11

CTCTGGGATAAGCCTGGGAAACCGGGTCTAAT ACCGGATATGACTTCCTGCCGCATGGTGGGGG GTGGAA

AGATTTTTTGGTTTTGGATGGACTCGCGGCCT ATCAGCTTGTTGGTGGGGTAATGGCCTACCAA GGCGAC

GACGGGTAGCCGGCCTGAGAGGGTGACCGGCC ACACTGGGACTGAGACACGGCCCAGACTCCTA CGGGAG

GCAGCAGTGGGGAATATTGCACAATGGGCG CAAGCCTGATGCAGCGACGCCGCGTGAGGG ATGACGGCCT

TCGGGTTGTAAACCTCTTTCAGCAGGGAAGAA GCGGAAGTGACGGTACCTGCAGAAGAAGCG CCGGCTAA

CTACGTGCCAGCAGCCGCGGTAATACGTAGGG CGCAAGCGTTGTCCGGAATTATTGGGCGTAAA GAGCTC

GTAGGCGGTTTGTCGCGTCTGCTGTGAAAGCC CGGGGCTCAACCCCGGGTCTGCAGTGGGTA CGGGCAGA

CTGGAGTGCAGTAGGGGAGACTGGAATTCCTG GTGTAGCGGTGAAATGCGCAGATATCAGGAGG AACACC

GATGGCGAAGGCAGGTCTCTGGGCTGTAACTG ACGCTGAGGAGCGAAAGCATGGGGAGCGAA CAGGATTA

GATACCCTGGTAGTCCATGCCGTAAACGTTGG GCACTAGGTGTGGGGGACATTCCACGTTTTCCGC GCCC

GTAGCTAACGCCC
The sequence of MT453912-Neomicrococcus lactis strain PR-F11

GAGAATTCCACGTTTTTCCGCGCCGTAGCTAA CGCATTAAGTGCCCCGCCTGGGGAGTACGGCC GCAAGG

CTAAAACTCAAAGGAATTGACGGGGGCCCGCA CAAGCGGCGGAGCATGCGGATTAATTCGAT GCAACGCG

AAGAACCTTACCAAGGCTTGACATGGGCCGGA TCGCCGCAGAAATGCGGTTTCCCTTCGGGG CCGGTTCA

CAGGTGGTGCATGGTTGTCGTCAGCTCGTGTC GTGAGATGTTGGGTTAAGTCCCGCAACGAGCG CAACCC

TCGTTCTATGTTGCCAGCGGTTCGGCCGGGGA CTCATAGGAGACTGCCGGGGTCAACTCGGA GGAAGGTG

GGGACGACGTCAAATCATCATGCCCCTTATGT CTTGGGCTTCACGCATGCTACAATGGCCGGTA CAAAGG

GTTGCGATACTGTGAGGTGGAGCTAATCCCAA AAAGCCGGTCTCAGTTCGGATTGAGGTCTGCAAC TCGA

CCTCATGAAGTCGGAGTCGCTAGTAATCGCAG ATCAGCAACGCTGCGGTGAATACGTTCCCGGGCC TTGT

ACACACCGCCCGTCAAGTCACGAAAGTTGGTA ACACCCGAAGCCGGTGGCCTAACCCTTTTGGG AGGGAG

CCGTCGAAGGTGGGACCGGCGATTGGGACTAA GTCGTAACAAGGTAACCGATAAGG 
Table 4 Antibacterial activity of culture filtrate of PR1, PR2, and PR3 against pathogenic bacteria

\begin{tabular}{|c|c|c|c|c|c|c|}
\hline Isolates & $\begin{array}{l}\text { Pathogenic bacteria } \\
\qquad(\mathrm{OD}=0.8)\end{array}$ & $\begin{array}{c}\text { Filter } \\
\text { sterilized }+ \\
\text { Autoclaved } \\
\text { Culture } \\
\text { filtrate } \\
50 \mu 1\end{array}$ & $\begin{array}{c}\text { Filter } \\
\text { sterilized }+ \\
\text { Autoclaved } \\
\text { Culture } \\
\text { filtrate } \\
100 \mu 1\end{array}$ & $\begin{array}{c}\text { Filter } \\
\text { sterilized }+ \\
\text { Proteinase } \\
\text { K Culture } \\
\text { filtrate } \\
50 \mu 1\end{array}$ & $\begin{array}{c}\text { Filter } \\
\text { sterilized }+ \\
\text { Proteinase } \\
\text { K Culture } \\
\text { filtrate } \\
100 \mu 1\end{array}$ & $\begin{array}{c}\text { Antibiotic } \\
\text { disc } \\
\text { Streptomycin } \\
(20 \mu \mathrm{l})\end{array}$ \\
\hline PR1 & $\begin{array}{l}\text { S. aureus } \\
\text { E. coli } \\
P . \text { aeruginosa } \\
\text { K. pneumoniae }\end{array}$ & $\begin{array}{l}8.5 \pm 0.1^{*} \\
6.0 \pm 0.1^{*} \\
7.5 \pm 0.1^{*} \\
8.5 \pm 0.1^{*}\end{array}$ & $\begin{array}{l}9.5 \pm 0.1^{*} \\
6,5 \pm 0.1^{*} \\
8.0 \pm 0.1^{*} \\
8.5 \pm 0.1^{*}\end{array}$ & $\begin{array}{l}9.5 \pm 0.1^{*} \\
5.5 \pm 0.1^{*} \\
9.5 \pm 0.1^{*} \\
8.5 \pm 0.1^{*}\end{array}$ & $\begin{array}{c}10.5 \pm 0.1^{*} \\
6.5 \pm 0.1^{*} \\
10.0 \pm 0.1^{*} \\
9.0 \pm 0.1^{*}\end{array}$ & $\begin{array}{l}17.5 \pm 0.1 * \\
18.0 \pm 0.1 \\
18.5 \pm 0.1 \\
18.0 \pm 0.2\end{array}$ \\
\hline PR2 & $\begin{array}{l}\text { S. aureus } \\
\text { E. coli } \\
\text { P. aeruginosa } \\
\text { K. pneumoniae }\end{array}$ & $\begin{array}{l}7.0 \pm 0.1^{*} \\
5.0 \pm 0.1^{*} \\
6.5 \pm 0.1^{*} \\
7.5 \pm 0.1^{*}\end{array}$ & $\begin{array}{c}8.0 \pm 0.1^{*} \\
5.5 \pm 0.1^{*} \\
7.5 \pm 0.1^{*} \\
7.5 \pm 0.1^{*}\end{array}$ & $\begin{array}{l}8.0 \pm 0.1^{*} \\
4.5 \pm 0.1^{*} \\
8.0 \pm 0.1^{*} \\
8.0 \pm 0.1^{*}\end{array}$ & $\begin{array}{l}8.0 \pm 0.1^{*} \\
5.5 \pm 0.1^{*} \\
9.0 \pm 0.1^{*} \\
8.5 \pm 0.1^{*}\end{array}$ & $\begin{array}{l}18.0 \pm 0.2^{*} \\
18.5 \pm 0.1 \\
18.0 \pm 0.1 \\
18.5 \pm 0.1\end{array}$ \\
\hline PR3 & $\begin{array}{l}\text { S. aureus } \\
\text { E. coli } \\
P . \text { aeruginosa } \\
\text { K. pneumoniae }\end{array}$ & $\begin{array}{l}6.0 \pm 0.1^{*} \\
4.0 \pm 0.1^{*} \\
6.5 \pm 0.1^{*} \\
7.0 \pm 0.1^{*}\end{array}$ & $\begin{array}{l}8.5 \pm 0.1^{*} \\
5.0 \pm 0.1^{*} \\
8.5 \pm 0.1^{*} \\
8.0 \pm 0.1^{*}\end{array}$ & $\begin{array}{l}7.5 \pm 0.1^{*} \\
5.0 \pm 0.1^{*} \\
7.5 \pm 0.1^{*} \\
8.5 \pm 0.1^{*}\end{array}$ & $\begin{array}{l}9.5 \pm 0.1^{*} \\
6.0 \pm 0.1^{*} \\
9.0 \pm 0.1^{*} \\
9.5 \pm 0.1^{*}\end{array}$ & $\begin{array}{c}18.5 \pm 0.2^{*} \\
18.0 \pm 0.5^{*} \\
18.0 \pm 0.2^{*} \\
17.5 \pm 0.1\end{array}$ \\
\hline
\end{tabular}

Results are expressed as antagonistic activity $(\mathrm{mm})$ of the isolate bacteria against pathogenic compared to control (mean $\pm \mathrm{SD}, n=3$ ). Values significantly different from control if ${ }^{*} \rho<0.05$ as analyzed by student t-test. Control value for all the pathogenic bacteria $6 \mathrm{~mm}$

PR1-Bacillus aryabhattai strain PR-D07, PR2-Arthrobacter humicola strain PR-F07, PR3-Neomicrococcus lactis strain PR-F11

\section{Phylogeny of PR1, PR2, and PR3}

The obtained sequences were compared with sequences in the Genbank nucleotide database. The identification of the species is done with the phylogenetic analysis neighbor with $98-100 \%$ similarity. Phylogenetic analysis and sequence alignment were carried out using the http://www.phylogeny.fr/simple_phylogeny.cgi. This indicates that collected strains are B. aryabhattai (PR1), A. humicola (PR2), and N. lactis (PR3) (Figs. 1, 2, and 3).

\section{Discussion}

Soil is found to be a rich source for various types of bacterial communities when compared to other environments and they are very well adapted to constantly varying soil environments. Competition among them for survival necessitates producing antibacterial compounds to eliminate the competitor. This is one of the reasons why soil bacteria are preferred for screening of antibacterial activity [30]. Numerous scientists have selected soil for the isolation of countless antibiotic-producing bacteria. Arifuzzaman et al. [31], a revealed 20 soil bacterial strains were active against the pathogenic microbes. Denizci [32] isolated 356 Streptomyces isolates from the soils in several regions of Turkey and screened for antibacterial activity. Dehnad et al. [33] have isolated 150 actinomycetes from soil samples of West of Iran for screening antibacterial activity against the test pathogens. Falkinham et al. [34] reported that soil bacteria form the basis for the production of nearly 500 antibiotics each year. The demand for bacterial antibiotics continues to increase globally because the pathogenic bacteria continue to acquire resistance to the antibiotics and many antibiotics proved that they are no longer potent against the infections $[18,19]$. It is reported that some Staphylococcus spp., Streptococcus spp., pseudomonads, and Enterobacteria, responsible for several human health issues, have developed resistance to many antibiotics [35].

This study is aimed to isolate soil bacteria that exhibit antibacterial activity. Out of 263 bacterial colonies isolated from soil samples, only 3 had antibacterial potential. The 3 active bacterial strains (B. aryabhattai strain PR-D07, A. humicola strain PR-F07, and N. lactis strain PR-F11), isolated and identified through molecular methods in this study are the first report on their antibacterial activity against all the human pathogens mentioned earlier. Any reports of antibacterial activity by these isolates and their preferential carbon and nitrogen source are not available so far.

Nike et al. [36] and Kaur et al. [37] have used the primary and secondary screening methods as done in our work for the isolation and screening of bacterial isolates. 
Table 5 Effect of carbon and nitrogen sources on antibacterial activity by PR1, PR2, and PR3

\begin{tabular}{|c|c|c|c|c|c|c|c|c|}
\hline $\begin{array}{l}\text { Pathogens } \\
(\mathrm{OD}=0.8)\end{array}$ & $\begin{array}{l}\text { Carbon } \\
\text { source }\end{array}$ & $\begin{array}{l}\text { Inhibition zone } \\
\text { (mm dia) PR1 }\end{array}$ & $\begin{array}{l}\text { Inhibition zone } \\
\text { (mm dia) PR2 }\end{array}$ & $\begin{array}{l}\text { Inhibition zone } \\
\text { (mm dia) PR3 }\end{array}$ & $\begin{array}{l}\text { Nitrogen } \\
\text { source }\end{array}$ & $\begin{array}{l}\text { Inhibition zone } \\
\text { (mm dia) PR1 }\end{array}$ & $\begin{array}{l}\text { Inhibition zone } \\
\text { (mm dia) PR2 }\end{array}$ & $\begin{array}{l}\text { Inhibition zone } \\
\text { (mm dia) PR3 }\end{array}$ \\
\hline S. aureus & Glucose & ++++ & ++ & ++ & Casein & ++ & +++ & ++ \\
\hline E. coli & & ++ & ++ & ++ & & ++ & ++ & ++ \\
\hline P. aeruginosa & & ++++ & ++ & ++ & & ++ & +++ & ++ \\
\hline $\begin{array}{l}\text { K. } \\
\text { pneumoniae }\end{array}$ & & ++++ & ++ & ++ & & ++ & +++ & ++ \\
\hline S. aureus & Sucrose & ++ & ++ & +++ & $\mathrm{NH}_{4} \mathrm{Cl}$ & ++ & ++ & ++ \\
\hline E. coli & & ++ & ++ & ++ & & ++ & ++ & ++ \\
\hline P. aeruginosa & & ++ & ++ & +++ & & ++ & ++ & ++ \\
\hline $\begin{array}{l}\text { K. } \\
\text { pneumoniae }\end{array}$ & & ++ & ++ & +++ & & ++ & ++ & ++ \\
\hline S. aureus & Glycerol & ++ & +++ & ++ & $\mathrm{NH}_{4} \mathrm{NO}_{3}$ & ++ & ++ & ++ \\
\hline E. coli & & ++ & ++ & ++ & & ++ & ++ & ++ \\
\hline P. aeruginosa & & ++ & +++ & ++ & & ++ & ++ & ++ \\
\hline $\begin{array}{l}\text { K. } \\
\text { pneumoniae }\end{array}$ & & ++ & +++ & ++ & & ++ & ++ & ++ \\
\hline S. aureus & Fructose & ++ & ++ & ++ & $\mathrm{NaNO}_{3}$ & ++ & ++ & ++ \\
\hline E. coli & & ++ & ++ & ++ & & ++ & ++ & ++ \\
\hline P. aeruginosa & & ++ & ++ & ++ & & ++ & ++ & ++ \\
\hline $\begin{array}{l}\text { K. } \\
\text { pneumoniae }\end{array}$ & & ++ & ++ & ++ & & ++ & ++ & ++ \\
\hline S. aureus & Galactose & ++ & ++ & ++ & Urea & ++++ & ++ & ++ \\
\hline E. coli & & ++ & ++ & ++ & & ++ & ++ & ++ \\
\hline P. aeruginosa & & ++ & ++ & ++ & & ++++ & ++ & ++ \\
\hline $\begin{array}{l}\text { K. } \\
\text { pneumoniae }\end{array}$ & & ++ & ++ & ++ & & ++++ & ++ & ++ \\
\hline S. aureus & Lactose & ++ & ++ & ++ & $\mathrm{NH}_{4} \mathrm{H}_{2} \mathrm{PO}_{4}$ & ++ & ++ & +++ \\
\hline E. coli & & ++ & ++ & ++ & & ++ & ++ & ++ \\
\hline P. aeruginosa & & ++ & ++ & ++ & & ++ & ++ & +++ \\
\hline $\begin{array}{l}\text { K. } \\
\text { pneumoniae }\end{array}$ & & ++ & ++ & ++ & & ++ & ++ & +++ \\
\hline S. aureus & Maltose & ++ & ++ & ++ & $\mathrm{KNO}_{3}$ & ++ & ++ & ++ \\
\hline E. coli & & ++ & ++ & ++ & & ++ & ++ & ++ \\
\hline P. aeruginosa & & ++ & ++ & ++ & & ++ & ++ & ++ \\
\hline $\begin{array}{l}\text { K. } \\
\text { pneumoniae }\end{array}$ & & ++ & ++ & ++ & & ++ & ++ & ++ \\
\hline S. aureus & Arabinose & ++ & ++ & ++ & $\mathrm{NH}_{4} \mathrm{SO}_{4}$ & ++ & ++ & ++ \\
\hline E. coli & & ++ & ++ & ++ & & ++ & ++ & ++ \\
\hline P. aeruginosa & & ++ & ++ & ++ & & ++ & ++ & ++ \\
\hline $\begin{array}{l}\text { K. } \\
\text { pneumoniae }\end{array}$ & & ++ & ++ & ++ & & ++ & ++ & ++ \\
\hline S. aureus & Control & ++ & ++ & ++ & Control & ++ & ++ & ++ \\
\hline E. coli & sucrose & ++ & ++ & ++ & $\mathrm{NH}_{4} \mathrm{NO}_{3}$ & ++ & ++ & ++ \\
\hline P. aeruginosa & & ++ & ++ & ++ & & ++ & ++ & ++ \\
\hline $\begin{array}{l}\text { K. } \\
\text { pneumoniae }\end{array}$ & & ++ & ++ & ++ & & ++ & ++ & ++ \\
\hline
\end{tabular}

++ 5-10 mm, +++ 10-15 mm, ++++ above $15 \mathrm{~mm}$

PR1-Bacillus aryabhattai strain PR-D07, PR2_-Arthrobacter humicola strain PR-F07, PR3-Neomicrococcus lactis strain PR-F11 
Table 6 The morphological and biochemical characterization of bacterial isolates

\begin{tabular}{|c|c|c|c|}
\hline Test & PR1 & PR2 & PR3 \\
\hline Gram Stain & + & + & + \\
\hline Motility & + & + & - \\
\hline Colony color & Opaque and off-white & Cream & Yellow pigmented colonies \\
\hline Cell shape & Rod-shaped & Rod-shaped & Cocci \\
\hline Spore forming & + & - & - \\
\hline Oxidase & + & - & - \\
\hline Catalase & + & + & + \\
\hline Amylase & + & - & - \\
\hline Gelatinase & - & & - \\
\hline Phosphatase & - & + & + \\
\hline Tryptophane deaminase & - & - & - \\
\hline Arginine dihydrolase & - & - & - \\
\hline Lysine decarboxylase & - & - & - \\
\hline Ornithine decarboxylase & - & - & - \\
\hline Glutamate decarboxylase & - & - & - \\
\hline Voges-Proskauer & + & - & - \\
\hline Nitrate reduction & - & - & + \\
\hline Hydrolysis of Casein & + & - & + \\
\hline Hydrolysis of starch & - & - & - \\
\hline Hydrolysis of urea & - & - & + \\
\hline Indole Production & - & - & - \\
\hline
\end{tabular}

Many scientists have adopted the agar well diffusion method for secondary screening of bacteria using cellfree culture filtrates [38-40]. Similar studies on different bacteria were carried out by Rafiq et al. [41] and their study suggested that most of the species belonging to the genus Bacillus are potential for the production of antibiotics. Our study also found that one of the active bacteria was $B$. aryabhattai.

In this study, all culture filtrates at $100 \mu \mathrm{l}$ inhibited the growth of all bacterial pathogens listed earlier. It shows that PR1, PR2, and PR3 displayed broadspectrum activity against both the Gram $(+)$ and Gram (-) bacteria. However, the zone of inhibition for $S$. aureus, $P$. aeruginosa, and $K$, pneumoniae was bigger than the inhibition zone for $E$. coli indicating that Gram $(+)$ bacteria are more vulnerable to antibiotics than Gram (-) bacteria. The difference in membrane constituents of Gram (+) and Gram (-) is responsible for the difference in susceptibility, outer polysaccharide membrane possessed by Gram (-) did not permit the entry of lipophilic solutes whereas the peptidoglycan layer of Gram (+) bacteria is not an effective barrier [42]. In their work, Ray et al. [43] reported that culture filtrates of B. aryabhattai LS11, isolated from wetland soils failed to inhibit E.coli at all concentrations.
In our studies, the filter-sterilized culture filtrate of $B$. aryabhattai (PR1) showed maximum antibacterial activity against all tested pathogens which is similar to the results of Yoshida et al. (38), who used the filter-sterilized culture filtrate of $B$. amyloliquefaciens against many bacteria. However, Onajobi et al. [44] reported that the culture filtrate of $B$. aryabhattai KNUC205 isolated from farmland soil showed antibacterial activity only against $P$. aeruginosa and failed to show any activity against $S$. aureus, E. coli, and K. pneumoniae, tested by them.

Autoclaving and proteinase $\mathrm{K}$ treatment of culture filtrate reduced the antibacterial activity against all tested pathogens. Reduction in the antibacterial activity of culture filtrate as a result of proteinase $\mathrm{K}$ treatment indicated that the antibacterial principle is proteinaceous [45]. Members of the genus Bacillus were found to produce different types of peptides which are responsible for the broad spectrum of antibacterial activity against pathogenic bacteria [46]. Proteins, whether they are a simple or complex group of polypeptides make pathways with several enzymatic steps using polyketide synthases and peptide synthetases to produce antibiotics (10). Meng et al. [47] and Siahmashteh et al. [48] have shown that Bacillus species are found to be a robust source of antibiotics against various pathogens. 
The antibacterial activity shown by soil bacteria is governed by the nutritional status of the soil which includes carbon and nitrogen sources. Therefore, optimization of essential substrates is required for the production of a high level of antibacterial compounds [14]. The effect of different carbon and nitrogen sources on antibacterial activity was studied as these have significant effects on bacterial metabolism. The priority of nutritional substrates widely varies among every isolate. In our studies, 3 different isolates preferred 3 different carbon and nitrogen sources. B. aryabhattai strain PR-D07 (PR1), A. humicola strain PR-F07 (PR2), and N. lactis strain PRF11 (PR3) preferred glucose, glycerol, and sucrose as carbon sources respectively. Hence, there is a difficulty in arriving at a common formula regarding the nutritional requirement for all isolates. Our results revealed that $1 \%$ glucose as the sole carbon source stimulated increased antibacterial activity more than other sugars in the case of the isolate $B$. aryabhattai strain PR-D07 (PR1). These results were in agreement with the earlier reports which stated that $1 \%$ glucose was the optimum carbon source for antibiotic production in Streptomyces sp. $[49,50]$ in Brevibacillus laterosporus EA62 [51] and Bacillus subtilis [52]. However, Pandey et al. [53] found that $2 \%$ of Dextrose is the preferred source by S. kanamyceticus. Dunia et al. [54] reported enhanced production of antibiotics by wheat bran as a carbon source in Streptomyces sp. whereas Alev Usta et al. [51] found that the antibiotic activity of Brevibacillus laterosporus EA62 was repressed by wheat bran but a higher growth rate was observed. Zhang et al. [55] found enhanced antibacterial activity if sucrose was used for the growth of $B$. amyloliquifaciens. El-Banna [56] had tested 5 different strains of B. megaterium, and their preference to carbon source significantly varied for enhanced antibacterial activity. According to their results, B. megaterium NB-3 and NB-6 utilized Glycerol, B. megaterium NB-4 and NB-5 used Glucose, and B. megaterium NB-7 preferred Fructose for enhanced antibiotic activity against tested bacteria. Glycerol as a carbon source displayed higher antibacterial activity by $B$. firmus and $B$. circulans, starch for B. stearothermophilus, and an unknown strain [57].

Similarly, preference for nitrogen source also differed among all the 3 isolates tested in the present study. $B$. aryabhattai strain PR-D07 (PR1) showed maximum antibacterial activity using urea than all other nitrogen sources. A. humicola strain PR-F07 (PR2) preferred casein and $N$. lactis strain PR-F11 (PR3) used $\mathrm{NH}_{4} \mathrm{H}_{2} \mathrm{PO}_{4}$ for antibacterial activity. Although the isolate $B$. aryabhattai strain PR-D07 (PR1) preferred urea, Zhang et al. [55] reported urea led to the loss of antibacterial activity in B. amyloliquifaciens and it preferred $\mathrm{NH}_{4} \mathrm{Cl}$ as the best nitrogen source for antibiotic activity.

In a study by Dunia et al. [54], yeast extract, ammonium sulfate, and beef extract as a supplement to wheat bran produced $249 \mathrm{U} / \mathrm{g}, 240 \mathrm{U} / \mathrm{g}, 220 \mathrm{U} / \mathrm{g}$ of antibiotic respectively by Streptomyces sp. AS4 which is comparatively higher than the wheat bran alone. Oskay [58] and Al-Ghazali and Omron, [59] have reported peptone as the excellent nitrogen source for Streptomyces sp. and Streptomyces sp. KGG32 respectively for antibiotic production.

Morphological and biochemical characterization of isolates PR1, PR2, and PR3 were carried out as it is a tool for preliminary identification of bacteria, and it is a conventional method followed by microbiologists all over the world [37, 60]. For the past several decades, most laboratories adopt microscopic identification and biochemical characterization to identify the bacteria [61]. As the bacteria do not have sufficient morphological features to confirm their identity, several procedures have been formulated based on their nutrition, metabolic activities, metabolic products, or enzymatic reactions which help in grouping and identifying the bacteria up to genus and species level $[62,63]$. The Gram staining results showed that the isolates PR1, PR2, and PR3 are Gram (+). The biochemical tests carried out in our studies matched with these isolates.

Phylogenetic analysis and sequence alignment of the isolates PR1, PR2, and PR3 revealed them as $B$.

\section{MT453908-Bacillus aryabhattai strain PR-D07 (PR1)}

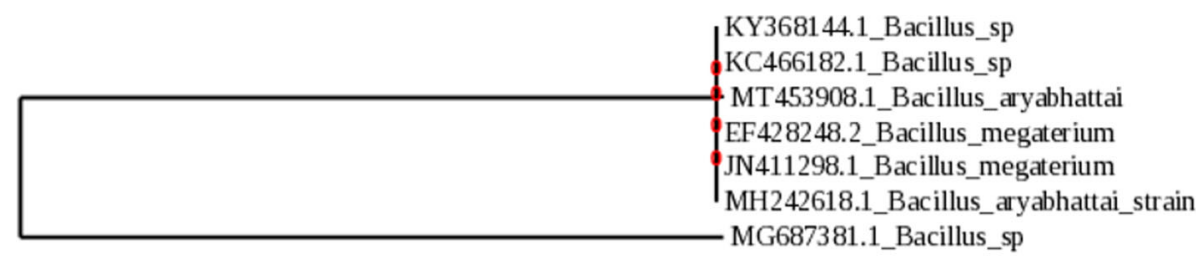

0.06

Fig. 1 Neighbor-joining tree showing the phylogenetic relationships of 165 rRNA gene sequences of $B$. aryabhattai. The scale bar indicates evolutionary distance 


\section{MT453911-Arthrobacter humicola strain PR-F07 (PR2)}

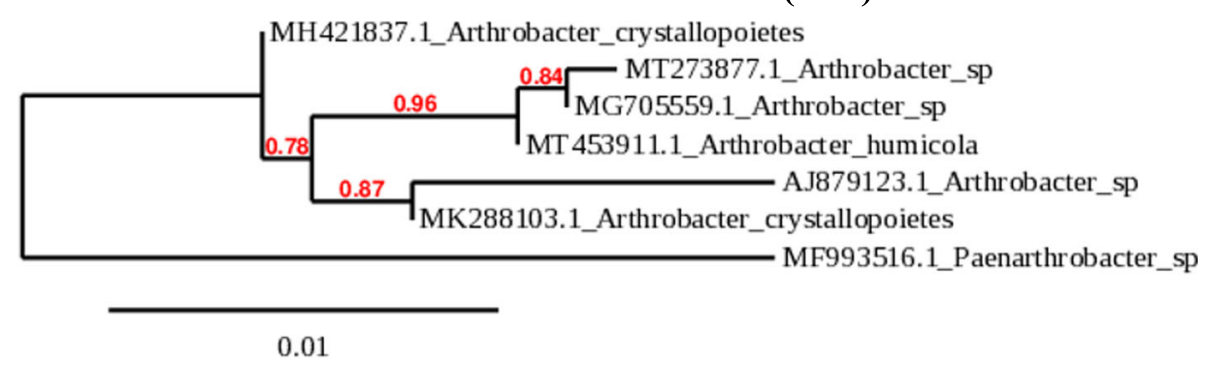

Fig. 2 Neighbor-joining tree showing the phylogenetic relationships of $16 S$ rRNA gene sequences of $A$. humicola. The scale bar indicates evolutionary distance

aryabhattai, A. humicola, and N.lactis. The isolate $B$. aryabhattai PR-D07 (PR1) displayed a high antibacterial activity than other isolates. Several reports confirmed the fact that many species of the genus Bacillus are potential antibiotic producers [41]. Ours is the first report on the antibacterial activity of $B$. aryabhattai against human pathogens $S$. aureus, E. coli, $P$. aeruginosa, and $K$. pneumoniae.

Apart from its antibacterial property, B. aryabhattai was reported to be the producer of many value-added products. Yaraguppi et al. [64] have reported that $B$. aryabhattai could be a promising candidate for exploring the production of biosurfactants relevant to the pharmaceutical industry. Paz et al. [65] have obtained several value-added products from $B$. aryabhattai by using different media. They suggested this bacterium could be used to degrade lignocellulose wastes and treating dyes from the textile industry. It indicates that $B$. arybhattai could be a potential organism to study in detail. The antibacterial activity shown by $B$. aryabhattai (isolate PR1) would be as effective as that of the commercial antibiotic provided further purification and characterization of antibiotic factor is carried out.

In the present work, the isolate PR2 was identified as A. humicola PR-F07 exhibited antibacterial activity on all test bacteria; however, its activity was comparatively lower than B. aryabhattai PR-D07vNo report is available on the antibiotic activity of $A$. humicola and ours is the first report of antibiotic activity by $A$. humicola. However, Munaganti et al. [66] have reported that modified yeast extract malt extract dextrose broth enhanced the bioactive compound formation in A. kerguelensis. According to their experimental results, lactose and peptone were the best carbon and nitrogen sources. Bacteria of the genus Arthrobacter are commonly found in the soil environment and Kageyama et al. [67] isolated this bacteria from the paddy field. The bioflocculants produced by $A$. humicola were reported to be used for sewage wastewater treatment replacing the chemically produced flocculants [68].

The isolate PR3 which showed antibacterial activity was identified as $N$. lactis PR-F11. This new species was proposed and described by Prakash et al. [69]. There is no report on the production of antibiotics by $N$. lactis so far. Ours is the first report on antibacterial activity by $N$. lactis. Biscupiak et al. [70] reported that Micrococcus luteus produced an antibiotic named Neoberninamycin. In another report by Kumari et al. [71], the crude yellow pigment of Micrococcus sp. OUS9 was active against both Gram (+) and Gram (-) bacteria, i.e., B. subtilis, K. pneumoniae. Salmonella sp., S. aureus, P. aeruginosa, and $E$. coli, No literature has been available on $N$. lactis

\section{MT453912-Neomicrococcus lactis strain PR-F11 (PR3)}

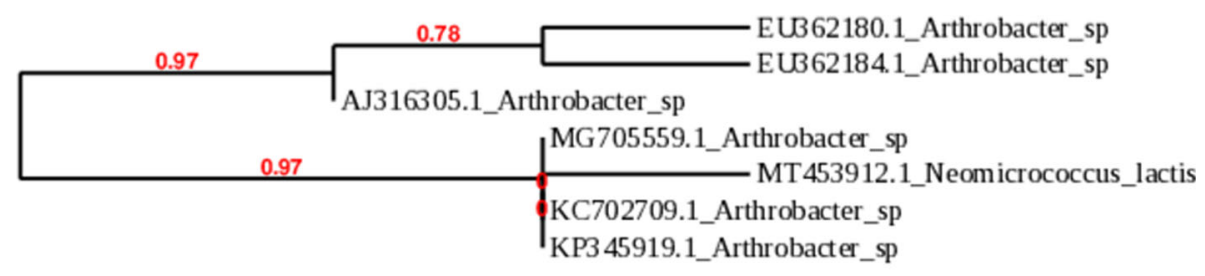

0.002

Fig. 3 Neighbor-joining tree showing the phylogenetic relationships of 165 rRNA gene sequences of $N$. lactis. The scale bar indicates evolutionary distance 
on its antibacterial activity except for the proposal for the creation of a new genus Neomicrococcus by Prakash et al. [70].

\section{Conclusion}

Our attempt to isolate soil bacteria having antibacterial activity yielded encouraging results. There are 3 bacterial isolates, hitherto not reported for antibiotic activity have been characterized and identified as $B$. aryabhattai, $A$. humicola, and $N$. lactis. These isolates were tested against human pathogens, S. aureus, E. coli, P. aerugi$n o s a$, and $K$. pneumoniae. Among the pathogens tested, the Gram-negative bacteria E. coli was slightly resistant compared to other Gram-positive pathogens. Filtersterilized culture filtrates had more antibacterial activity than autoclaved and proteinase K-treated culture filtrates. All isolates preferred different carbon and nitrogen sources for their enhanced activity. In our study, $B$. aryabhattai showed good antibacterial activity than the other two isolates. All the isolates showed broadspectrum antibiotic activity, and further purification and standardization processes are required to compare the efficacy with all available antibiotics. We conclude that all these 3 bacteria are potential candidates for further research on their antibacterial properties.

\section{Acknowledgements}

The authors wish to express their gratitude to the Department of Biotechnology and Genetics, M. S. Ramaiah College of Arts Science and Commerce, Bengaluru, for providing the laboratory facility.

\section{Authors' contributions}

PR: Carried out molecular identification of bacteria and sequencing and analysis of 165 rRNA

SGK: Selection of study area and soil sample collection. Primary screening, isolation, and maintenance of bacteria. Performed experiments on perpendicular streaking method and seed overlay method KS: Secondary screening of antimicrobial activities of pure isolates. Analyzed the effect of filter sterilization, carbon and nitrogen sources, and proteinase $\mathrm{K}$ treatment on antibiotic activity

ML: Carried our morphological and biochemical characterization of bacteria isolated genomic DNA from bacterial samples

All authors read and approved the final manuscript.

\section{Authors' information}

Not applicable

\section{Funding}

Not applicable

\section{Availability of data and materials}

The datasets used and/or analyzed during the current study are available from the corresponding author on reasonable request.

\section{Declarations}

Ethics approval and consent to participate

Not applicable

\section{Consent for publication}

Not applicable

\section{Competing interests}

The authors declare that they have no competing interests.

Received: 2 November 2020 Accepted: 28 July 2021

Published online: 18 August 2021

\section{References}

1. Foster JW, Woodruff HB (2010) Antibiotic substances produced by bacteria. Ann N Y Acad Sci 1213:125-136

2. Li J, Mara P, Schubotz F, Sylvan JB, Burgaud G, Klein F, Beaudoin D, Wee SY, Dick HJB, Lott S, Cox R, Meyer LAE, Quémener M, Blackman DK, Edgcomb VP (2020) Recycling and metabolic flexibility dictate life in the lower oceanic crust. Nature 579:250-255

3. Mocali S, Chiellini C, Fabiani A, Decuzzi S, Pascale D, Parrilli E, Tutino ML, Perrin E, Bosi E, Fondi M, Giudice AL, Renato FR (2017) Ecology of cold environments: new insights of bacterial metabolic adaptation through an integrated genomic-phenomic approach. Sci Rep 7:839

4. Schuler CG, Havig JR, FHamilton TL (2017) Hot spring microbial community composition, morphology, and carbon fixation: implications for interpreting the ancient rock record. Front Earth Sci. https://doi.org/10.3389/feart.2017. 00097

5. Ali I, Prasongsuk S, Akbar A, Aslam M, Lotrakul P, Punnapayak H, Rakshit SK (2016) Hypersaline habitats and halophilic microorganisms. Maejo Int J Sci Technol 10:330-345

6. Pathak SP, Gopal K (2008) Prevalence of bacterial contamination with antibiotic-resistant and enterotoxigenic fecal coliforms in treated drinking water. J Toxicol Environ Health 71:427-433

7. Nilsson LO, Hüttl RF, Johansson UT, Jochheim H (1995) Selected papers from the CEC/IUFRO Symposium on Nutrient Uptake and Cycling in Forest Ecosystems. Plant Soil 168(169):5-13.F

8. Rotich MC, Magir E, Bii C, Maina N (2017) Bio-prospecting for broadspectrum antibiotic-producing actinomycetes isolated from virgin soils in Kericho county, Kenya. Adv Microbiol 7:1

9. Baniya A, Singh S, Singh M, Nepal P, Adhikari M, Aryal S, Adhikari A (2019) Isolation and screening of antibiotics producing Streptomyces spp from the soil collected around the root of Alnus nepalensis from Godawari. Nepal J Biotechnol 6:46-56

10. Demain AL, Fang A (2000) In: Fletcher A (ed) The natural functions of secondary metabolites. Advances in biochemical engineering/ biotechnology: history of modern biotechnology I, vol 69. Springer, Berlin, pp 2-39

11. Molinari G (2009) Natural products in drug discovery, present status, and perspectives. Pharm Biotechnol 655:13-27

12. Hassan SA, Hanif E, Zohra RR (2014) Isolation and screening of soil bacteria for potential antimicrobial activity. Fuuast J Biol 4:217-219

13. Hibbing ME, Fuqua C, Parsek MR, Peterson SB (2010) Bacterial competition: surviving and thriving in the microbial jungle. Nat Rev Microbiol 8:15-25

14. Sethi S, Kumar R, Gupta S (2013) Antibiotic production by microbes isolated from soil. Int J Pharm Sci Res 4:2967-2973

15. Huck TA, Porter N, Bushell ME (1991) Positive selection of antibiotic producing soil isolates. J Gen Microbiol 137:2321-2329

16. Marahiel MA, Nakano MM, Zabar P (1993) Regulation of peptide antibiotic production in Bacillus. Mol Microbiol 7:631-636

17. Van Boeckel TP, Gandra S, Ashok A, Caudron Q, Grenfell BT, Levin SA, Laxminarayan R (2014) Global antibiotic consumption from 2000 to 2010: an analysis of national pharmaceutical sales data. Lancet Infect Dis 14:742-750. https://doi.org/10.1016/S1473-3099(14)70780-7

18. Mayers DL, Lerner SA, Ouelette M (2009) Antimicrobial drug resistance C: clinical and epidemiological aspects. Springer Dordrecht Heidelberg, London 2:681-1347

19. Guschin A, Ryzhikh P, Rumyantseva T, Gomberg M, Unemo M (2015) Treatment efficacy, treatment failures, and selection of macrolide resistance in patients with a high load of Mycoplasma genitalium during treatment of male urethritis with Josamycin. BMC Infect Dis 15:1-7

20. Martin I, Sawatzky P, Liu G, Mulvey MR (2015) Antimicrobial resistance to Neisseria gonorrhoeae in Canada: 2009-2013 Can. Commun Dis Rep 41:4041

21. Gerits E, Blommaert E, Lippell A, O'Neill AJ, Weytjens B, De Maeyer D, Fierro AC, Marchal K, Marchand A, Chaltin P, Spincemaille P, De Brucker K, Thevissen K, Cammue BP, Swings T, Liebens V, Fauvart M, Verstraeten N, Michiels J (2016) Elucidation of the mode of action of a new antibacterial 
compound active against Staphylococcus aureus and Pseudomonas aeruginosa. PLoS One 11:e0155139

22. Kumarasamy KK, Toleman MA, Walsh TR, Bagaria J, Butt F, Balakrishnan R, Chaudhary U, Doumith M, Giske CG, Irfan S, Krishnan P, Kumar AV, Maharjan S, Mushtaq S, Noorie T, Paterson DL, Pearson A, Perry C, Pike R, Rao B, Ray U, Sarma JB, Sharma M, Sheridan E, Thirunarayan MA, Turton J, Upadhyay S, Warner M, Welfare W, Livermore DM, Woodford N (2010) Emergence of a new antibiotic resistance mechanism in India, Pakistan, and the UK: a molecular, biological, and epidemiological study. Lancet Infect Dis 10:597602

23. Torres-Cortes G, Millan V, Ramirez-Saad HC, Nisa-Martinez R, Toro N, Martinez-Abarca $F$ (2011) Characterization of novel antibiotic resistance genes identified by functional metagenomics on soil samples. Environ Microbiol 13:1101-1114

24. Pederson JC (1992) Natamycin as a fungicide in agar media. Appl Environ Microbiol 58:1064-1066

25. Liao P, Zhao JX, Shaobo L (2013) Effects of natamycin on the elimination of fungal contamination in rice and Arabidopsis thaliana tissue cultures for Agrobacterium mediated transformation. Res J Biotechnol 8:3-9

26. Madigan MT, Martiko JM, Parker J (1997) Antibiotics: isolation and characterization. In: Madigan MT (ed) Brock Biology of Microorganisms, 8th edn. Prentice-Hall International Inc, New Jersey, pp 440-442

27. Gislin D, Sudarsanam D, Antony Raj G, Baskar K (2018) Antibacterial activity of soil bacteria isolated from Kochi, India and their molecular identification. J Genet Eng Biotechnol 16:287-294

28. Bauer AW, Kirby WM, Sherris JC, Turck M (1966) Antibiotic susceptibility testing by a standardized single disk method. Am J Clin Pathol 36:493-496

29. Sambrook JF, Russell DW (2001) Molecular Cloning: A Laboratory Manual, Third Edition. Cold Spring Harbor Laboratory Press, New York Catalog Number M8265

30. Niharika C, Kumar S (2017) Antibiotics producing soil microorganisms. In: Antibiotics and antibiotics resistance genes in soils, pp 1-18

31. Arifuzzaman M, Khatun MR, Rahman H (2010) Isolation and screening of actinomycetes from Sundarbans soil for antibacterial activity. Afr J Biotechnol 9:4615-4619

32. Denizci AA (1996) EgeveDoÛuKaradenizbl gesitopraklar indenizoleed ilenaktino misetlerden antibakteri ya lantibiyotik lerinaranmasÝve. retimi. Zerin ebiraraßtÝr ma, Doctoral thesis (in Turkish), Institute of Science and Technology Ege University, Turkey

33. Dehnad A, Parsa L, Bakhshi R, Soofiani SA, Mokhtarzadeh A (2010) Investigation antibacterial activity of Streptomycetes isolates from soil samples, West of Iran. Afr J Microbiol Res 4:1542-1549

34. Falkinham JO, Wall TE, Tanner JR, Tawaha K, Alali FQ, Li C, Oberlies NH (2009) Proliferation of antibiotic-producing bacteria and concomitant antibiotic production as the basis for the antibiotic activity of Jordan's red soils. Appl Environ Microbiol 75:2735-2741. https://doi.org/10.1128/AEM.001 04-09

35. Neu HC (1992) The crisis in antibiotic resistance. Science. 257:1064-1073. https://doi.org/10.1126/science.257.5073.1064

36. Nike AR, Hassan SA, Ajilolakewu BAF (2013) Soil screening of antibioticproducing microorganisms. Adv Environ Biol 7:7-11

37. Kaur S, Kaur J, Pankaj PP (2014) Isolation and characterization of antibiotic producing microorganisms from soil samples of a certain area of Punjab region of India. Int J Pharm Clin Res 6:312-315

38. Yoshida S, Hiradate S, Tsukamoto T, Hatakeda K, Shibata A (2001) Antimicrobial activity of culture filtrate of Bacillus amyloliquefaciens RC-2 isolated from mulberry leaves. Phytopathology 91:181-187

39. Ahmed Sheik HM (2010) Antimicrobial activity of certain bacteria and fungi isolated from soil mixed with human saliva against pathogenic microbes causing dermatological diseases. Saudi J Biol Sci 17:331-339

40. Lau SKP, Teng JLL, Ho CC, Woo PCY (2015) Gene amplification and sequencing for bacterial identification. Methods Microbiol 42:433-464

41. Rafiq A, Khan SA, Akbar A, Shafi M, Ali I, Rehman FU, Rashid R, Shakoor G, Anwar M (2018) Isolation and identification of antibiotic-producing microorganisms from the soil. Int J Pharm Sci Res 9:1002-1011

42. Zgurskaya HI, Löpez CA, Gnanakaran S (2015) Permeability Barrier of GramNegative Cell Envelopes and Approaches To Bypass It. ACS Infect Dis 1:512522

43. Ray S, Datta R, Bhadra P, Chaudhuri B, Mitra AK (2012) From space to earth: Bacillus aryabhattai found in the Indian sub-continent. Biosci Discov 3:138145
44. Onajobi IB, Idowu EO, Adeyemi JO, Samson OJ, Ogunyinka PI, Fagade OE (2020) In vitro antibacterial activities and molecular characterization of bacterial species isolated from farmlands against selected pathogens. Biotechnol Rep. https://doi.org/10.1016/j.btre.2020.e00513

45. Sharma G, Dang S, Gupta S, Gabrani R (2018) Antibacterial activity, cytotoxicity, and the mechanism of action of bacteriocin from Bacillus subtilis GAS101. Med Princ Pract 27:186-192

46. Sumi CD, Yang BW, Yeo IC, Hahm YT (2015) Antimicrobial peptides of the genus Bacillus: a new era for antibiotics. Can J Microbiol. https://doi.org/1 0.1139/cjm-2014-0613

47. Meng QX, Jiang HH, Hanson LE, Hao JJ (2012) Characterizing a novel strain of Bacillus amyloliquefaceins BACO3 for potential biological control application. J Appl Microbiol 113:1165-1175

48. Siahmashteh F, Siciliano I, Banani H, Hamidi-Esfahani Z, Razzaghi-Abyaneh M, Gullino ML, Spadaro D (2017) Efficacy of Bacillus subtilis and B. amyloliquefaciens in the control of Aspergillus parasiticus on growth and aflatoxin production in Pistachio. Int. J. Food Microbiol 254:47-53

49. Raytapadar S, Paul AK (2001) Production of an antifungal antibiotic by Streptomyces aburaviensis IDA-28. Microbiol Res 155:315-323

50. Ripa FA, Nikkon F, Zaman S, Khondkar P (2009) Optimal conditions for antimicrobial metabolites production from a new Streptomyces sp. Rupa08pr isolated from Bangladeshi soil. Mycobiology. 37:211-217

51. Alev Usta AK, Demirkani E, Cengiz M, Sevgi T, Zeren B, Abdou M (2018) Optimization of culture medium for the production and partial purification and characterization of an antibacterial activity from Brevibacillus laterosporusStrain EA62. Romanian Biotechnol Lett. https://doi.org/10.26327/ RBL2018.217

52. Rukmani M, Sahoo D, Dalei J, Ray R (2015) Production, purification, and characterization of bacitracin from Bacillus subtilis. Pharma Innov J 3:77-82

53. Pandey A, Shukla A, Majumdar SK (2005) Utilization of carbon and nitrogen sources by Streptomyces kanamyceticus M 27 for the production of an Antibacterial antibiotic. Afr J Biotechnol 4:909-910

54. Dunia A, Farraj A, Varghese R, Vágvölgyi C, Elshikh MS, Alokda AM, Mahmoud AH (2020) Antibiotics production in optimized culture condition using low-cost substrates from Streptomyces sp. AS4 isolated from mangrove soil sediment. J King Saud Univ Sci 32:1528-1535

55. Zhang W, Wei L, Xu R, Lin G, Xin H, Lv Z, Qian H, Shi H (2020) Evaluation of the antibacterial material production in the fermentation of Bacillus amyloliquefaciens-9 from white spotted bamboo shark (Chiloscyllium plagiosum), Mar. Drugs 18:119. https://doi.org/10.3390/md1802011

56. El-Banna NM (2005) Effect of carbon source on the antimicrobial activity of the air flora. World J Microbiol Biotechnol 21:1451-1454

57. Massadeh MI, Mahmoud SM (2019) Antibacterial activities of soil bacteria isolated from Hashemite University area in Jordan. Jordan J Biol Sci 12:511513

58. Oskay M (2011) Effects of some environmental conditions on biomass and antimicrobial metabolite production by Streptomyces sp. KGG32. Int J Agric Biol 13:317-324

59. Al-Ghazali LH, Omron R (2017) Optimization of medium composition for antibacterial metabolite production from Streptomyces sp. Asian J Pharmaceut Clin Res 10:381-385

60. Diddi K, Chaudhry R, Sharma N, Dhawan B (2013) Strategy for identification \& characterization of Bartonellahenselae with conventional \& molecular methods. Indian J Med Res 137:380-387

61. Martiny D, Busson L, Wybo I, El Haj RA, Dediste A, Vanderberg O (2012) Comparison of the Microflex It and Vitek ms systems for routine identification of bacteria by matrix-assisted laser desorption ionization-time of flight mass spectrometry. J Clin Microbiol 50:1313-1325

62. Busch U, Nitschko H (1999) Methods for the differentiation of microorganisms. Journal of Chromatography. B. Biomed Sci Appli 7:263-278

63. Romeu B, Salazar P, Navarro A, Lugo D, Hernadez U, Rojas N, Eslava C (2010) Utilidad del sistema VITEK en la identificación y determinación de la susceptibilidad antimicrobiana de bacterias aisladas de ecosistemas dulceacuícolas. CENIC 41:1-9

64. Yaraguppi DA, Deshpande SH, Bagewadi ZK, Sudeep K, Muddapur UM (2021) Genome analysis of Bacillus aryabhattai to identify biosynthetic gene clusters and in silico methods to elucidate its antimicrobial nature. Int J Pept Res Ther. https://doi.org/10.1007/s10989-021-10171-6

65. Paz A, Carballo J, Pérez MJ, Domínguez JM (2016) Bacillus aryabhattai BA03: a novel approach to the production of natural value-added compounds. World J Microb Biotechnol 32:159 
66. Munaganti RK, Muvva V, Konda S, Naragani K, Mangamuri UK, Dorigondla KR, Akkewar DM (2016) Antimicrobial profile of Arthrobacter kerguelensis VLRK_09 isolated from Mango orchards. Braz J Microbiol 247:1030-1038

67. Kageyama A, Morisaki K, Omura S, Takahashi Y (2008) Arthrobacter oryzae sp. nov. and Arthrobacter humicola sp. nov. Int I Syst Evol Microbiol 58:53-56

68. Agunbiade MO, Van Heerden E, Pohl CH, Ashafa AT (2017) Flocculating performance of a bioflocculant produced by Arthrobacter humicola in sewage wastewater treatment. BMC Biotechnol 17:51. https://doi.org/10.11 86/s12896-017-0375-0

69. Prakash O, Sharma A, Nimonkar Y, Shouche YS (2015) Proposal for creation of a new genus Neomicrococcus gen. nov. to accommodate Zhihengliuella aestuarii and Micrococcus lactis as Neomicrococcus aestuarii comb. nov. and Neomicrococcus lactis comb. nov. Int J Syst Evol Microbiol 65:3771-3776

70. Biskupiak JE, Meyers E, Gillum AM, Dean L, Trejo WH, Kirsch DR (1998) Neoberninamycin, a new antibiotic produced by Micrococcus luteus. J Antibiot (Tokyo) 41:684-687

71. Kumari KS, Shivakrishna P, Al-Attar AM, Ganduri VSR (2020) Antibacterial and cytotoxicity activities of bioactive compounds from Micrococcus species OUS9 isolated from seawater. J King Saud Univ Sci 32:2818-2825

\section{Publisher's Note}

Springer Nature remains neutral with regard to jurisdictional claims in published maps and institutional affiliations.

\section{Submit your manuscript to a SpringerOpen ${ }^{\circ}$ journal and benefit from:}

- Convenient online submission

- Rigorous peer review

- Open access: articles freely available online

- High visibility within the field

- Retaining the copyright to your article

Submit your next manuscript at $\boldsymbol{\nabla}$ springeropen.com 